Mihailo Mrdak ${ }^{1 *}$, Časlav Lačnjevac ${ }^{2}$, Marko Rakin ${ }^{3}$, Darko Veljić ${ }^{4}$, Nikola Bajić ${ }^{4}$

${ }^{1}$ Istraživački i razvojni Centar, IMTEL Komunikacije a.d., Beograd, Srbija, ${ }^{2}$ Univerzitet u Beogradu, Poljoprivredni fakultet, Beograd, Srbija, ${ }^{3}$ Univerzitet u Beogradu, Tehnološko-metalurški fakultet, Beograd, Srbija, ${ }^{4}$ Techno experts d.o.o - Istraživački i razvojni Centar, IHIS, Belgrade, Srbija
Scientific paper

ISSN 0351-9465, E-ISSN 2466-2585

UDC: $546.77: 620.198: 620.172$

doi:10.5937/zasmat $1904336 \mathrm{M}$

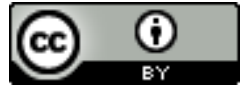

Zastita Materijala $60(4)$ 336 - 341 (2019)

\title{
Characterization of vacuum plasma spray NiCoCrAlY coating resistant to high temperature oxidation
}

\begin{abstract}
Protective vacuum plasma spray VPS - NiCoCrA/Y coating is used on sections of gas turbines to allow for longer and more reliable operation of sections exposed to aggressive effects of high temperature oxidation. Depositing of NiCoCrAlY alloy powder was done with the vacuum plasma spray system of the Plasma Technik - AG Companyon the A-2000 control unit using the plasma F4 gun. To test the mechanical properties and microstructure of the NiCoCrA/Y coating, the powder was deposited on C.4171 (X15Cr13 EN10027) steel substrates.To examine the microstructure of the coating in the heat-treated state, the powder was deposited on an IN738LC alloy substrate, which was pre-heated to a temperature of 750 to $800^{\circ} \mathrm{C}$ before deposition of the powder. The coating with the IN738LC alloy substrate was heat-treated at $1150^{\circ} \mathrm{C}$ for 2 hours in anargon shielded atmosphere. Mechanical testing of the microhardness of the coating was done using the $H V_{0.3}$ method and the tensile bond strength using the tension method. The morphology of the powder particles and the morphology of the surface of the deposited coating were examined using a scanning electron microscope (SEM). The microstructure of coating layers in deposited state was tested on an optical microscope (OM). After thermal treatment, etching of the coating was done in the reagent $\mathrm{CuSO}_{4}+\mathrm{HCl}$ aqueous solution. Analysis of the microstructure of the coating after etching was performed on the SEM, on the basis of which a score of the quality of the diffusion VPS - NiCoCrAlY coating was given.
\end{abstract}

Keywords: vacuum plasma spraying process, NiCoCrAY, microstructure, microhardness, tensile bond strength.

\section{INTRODUCTION}

Surface engineering plays an important role in the functioning of turbine engine components exposed to high temperatures. Each coating must offer protection, to the working parts of the engine within a specified time at a high temperature, from destructive effects of corrosion, oxidation and erosion. For the protection of surfaces of the superalloys from damaging effects of hightemperature oxidation and hot corrosion developed was a specific group of diffusion coatings type MeCrAlY. The MeCrAlY coatings (where $\mathrm{Me}=\mathrm{Ni}$, $\mathrm{Co}, \mathrm{Fe}$ or their respective mutual combination) are usedon parts as independent coatings and as bond coatings for thermal barriers [1-4].

\footnotetext{
${ }^{*}$ Corresponding autor: Mihailo Mrdak

E-mail: drmrdakmihailo@gmail.com

Paper received: 20. 05.2019.

Paper accepted: 30. 07. 2019.

Paper is available on the website:

www.idk.org.rs/casopis
}

Protective coatings are used on components of gas turbines to enable more reliable and longer operating of gas turbines. The operating environment of gas turbines is extremely sharp. Hot section components such as turbine blades must withstand the stresses and tough working conditions at temperatures of $900^{\circ} \mathrm{C}$ to $1000^{\circ} \mathrm{C}$. Alloy structures that make up the hot sections of gas turbine engines are developed with optimum mechanical properties and coatings to provide good resistance to the working environment. Some of the most important groups of diffusion coatings are NiCrAIY, CoCrAIY, CoNiCrAlY, NiCoCrAlY. NiCoCrAlY coatings are generally the most resistant to high temperature oxidation, while the CoNiCrAlY coatings provide better resistance to hot corrosion [5]. The primary objective of depositing the NiCoCrAlY coatings on the working surfaces of the parts exposed to high temperatures is surface protection which is based on: establishment of thermodynamic stable oxides on the coating surface, slow growth of oxides and good adhesion of oxidesto the coatingbase. For 
this reason, the coating is comprised of three key elements: aluminum, chromium and yttrium [6]. When designing a coating in addition to the resistance to oxidation and corrosion important are also mechanical properties, adhesion and metallurgical stability of the designed coatings. Aluminum has the greatest influence on oxidation resistance of the NiCoCrAIY coating. It forms the protective $\alpha-\mathrm{Al}_{2} \mathrm{O}_{3}$ oxide which is stable and slowly growing. This effect of Al generally increases with higher concentration. However, too much increase in the content of $\mathrm{Al}$ may lead to a significant decrease in toughness of the NiCoCrAlY coating [7]. The typical aluminum content is 10 to $12 \mathrm{wt} . \%$. Aluminum is added to the alloys NiCoCrAIY or CoNiCrAIY to form the $\beta-(\mathrm{Ni}, \mathrm{Co})$ phase, which serves as a reservoir of Al so that on the surface of the coating a stable protective oxide layer of $\alpha$ $\mathrm{Al}_{2} \mathrm{O}_{3}$ is formed, which prevents the diffusion of oxygen into the inner layers of the coating. Chromium also effectively reduces the diffusion of oxygen in the alloy by lowering the activity of oxygen and by stabilizing the $\alpha-\mathrm{Al}_{2} \mathrm{O}_{3}$ phase [7].

It should be noted that $\mathrm{Cr}_{2} \mathrm{O}_{3}$ decomposes into a volatile $\mathrm{CrO}_{3}$ oxide at temperatures above $900^{\circ} \mathrm{C}$ [8]. Cobalt generally increases the resistance to oxidation when the concentration of cobalt decreases. The CoNiCrAIY alloy with aluminum produces the $\beta$-CoAl phase which provides improved resistance to sulfidation, while nickel from the NiCoCrAIY alloy forms a number of phases with high melting points such as $\mathrm{Y}-\mathrm{Ni}, \mathrm{Y}^{\prime}-\mathrm{Ni}_{3} \mathrm{Al}$ and the $\beta$ $\mathrm{NiAl}$ phase, which provides enhanced oxidation resistance. The addition of nickel to the triple alloy of $\mathrm{Co}$ - $\mathrm{Cr}$ - Al can reduce the process of interaction between the coating and the superalloy. A reactive element such as yttrium, which is used in this coating, enhances binding of oxide to the upper surface of the coating. The typical content of yttrium is from 0.05 to $0.1 \mathrm{wt} \%$ and is sufficient to increase adhesion of the oxide to the base of the coating and reduce the rate of oxidation of the coating. Also, a high concentration of yttrium causes segregation of yttrium along the oxide grain boundaries. This could increase the diffusion of oxygen along the grain boundaries and thus increase the rate of oxidation, in comparison to lower concentrations of yttrium [9-11]. MeCrAIY alloys typically show a two-phase microstructure of $y+\beta$. The $y-$ phase represents a solid solution of $\mathrm{Ni}$, Co and $\mathrm{Cr}$. The $\beta-(\mathrm{Ni}, \mathrm{Co}) \mathrm{Al}$ phase resulting from the $\beta-\mathrm{NiAl}$ and $\beta-\mathrm{CoAl}$ phases is essential to coating protection. Resistance to high temperature oxidation of the coating is directly related to the amount of $\beta-\mathrm{NiAl}$ phase was present in the NiCoCrAIY coating. The $\beta$-phase occurs in a variety of morphologies, which are related to different cooling rates associated with the different particle size of the powder during spraying. If the ratio of $\mathrm{Ni}$ and $\mathrm{Co}$ is high enough a $\mathrm{Y}^{\prime}-\mathrm{Ni}_{3} \mathrm{Al}$ phase can also be formed [12]. The general structure of theNiCoCrAIY coating in deposited state is essentially two-phased, and consists of a precipitate of the $\beta$ - (NiAl) phase evenly distributed in the base of the $\gamma$ - phase which is a solid solution of cobalt and chromium in nickel $\mathrm{Y}-\mathrm{Ni}(\mathrm{Co}, \mathrm{Cr})$. At high temperatures of $1100^{\circ} \mathrm{C}-1150^{\circ} \mathrm{C}$ due to oxidation and formation of the TGO zone on the surface of the coating, results in changes in the coating structure and the gradual transformation of the $\beta-(\mathrm{NiAl})$ phase to the $\mathrm{Y}^{\prime}\left(\mathrm{Ni}_{3} \mathrm{Al}\right)$ phase that weakens with aluminum [13,14]. After heattreatment the microstructure of the NiCoCrAIY coating consists of a solid solution of cobalt and chromium in nickel $\mathrm{y}-\mathrm{Ni}(\mathrm{Co}, \mathrm{Cr})$, which contains the precipitates of the $\beta-\mathrm{NiAl}$ phase and precipitates of the $\left.\gamma^{\prime}-(\mathrm{Ni}, \mathrm{Cr})_{3} \mathrm{Al}\right)$ phase $[15,16]$. The $\beta$-phase grains rich in aluminum gradually with aluminum consumption convert to $\mathrm{Y}^{\prime}$ islands. The structure and properties of these coatings are influenced by chemical composition and production technology. In practice, the most commonly used technique for the production of MCrAIY coatings is the vacuum plasma spraying process - VPS.

The aim of this study was to, using vacuum plasma spray technology, deposit diffusion NiCoCrAIY coating layers with mechanical and structural characteristics which will provide sections of gas turbine engines good protection against destructive impactof high-temperature oxidation. The deposition of powder was done with a vacuum plasma spray system of the Plasma Technik AG Company, which has an A-2000 control panel and a F4 plasma gun. To examine the microstructure of the coating in heat-treated state, the coating was deposited on an IN738LC alloy substrate, which before deposition of the powder was pre-heated at a temperature of 750 to $800^{\circ} \mathrm{C}$. After deposition of the powder, the diffusion NiCoCrAIY coating was, together with the substrate, thermally treated at $1150^{\circ} \mathrm{C}$ for 2 hours in a protective atmosphere of argon. Based on the analysis of the coating in deposited and heat-treated state the assessment of the quality of the coating was made.

\section{EXSPERIMENTAL PART}

\subsection{Materials and experimental details of plasma spray coatings deposition}

For the production of the VPS-NiCoCrAIY coating the powder used was from the Sulzer Metco Company labeled Amdry365-1, which is used to protect the substrate from high temperature oxidation and corrosion at temperatures $\mathrm{t} \leq 1050^{\circ} \mathrm{C}$ [17]. The NiCoCrAIY powder was produced by gas atomization of the liquid melt of a nickel alloy containing 18.0 - 28.0wt.\%Co, 13.0 - 21.0wt.\%Cr, 
$10.0-15.0 w t . \% \mathrm{Al}, 0.1-0.8 w t . \% \mathrm{Y}$ and the restis $\mathrm{Ni}$ untilit is balanced out. The powder was produced with a range of powder particlegranulationfrom $5 \mu \mathrm{m}$ to $45 \mu \mathrm{m}$. The produced powder particles are spherical and homogeneous. Figure 1 shows the SEM photo micrograph of the morphology of the powder particles, andseen are spherical NiCoCrAl1Ypowder particles.

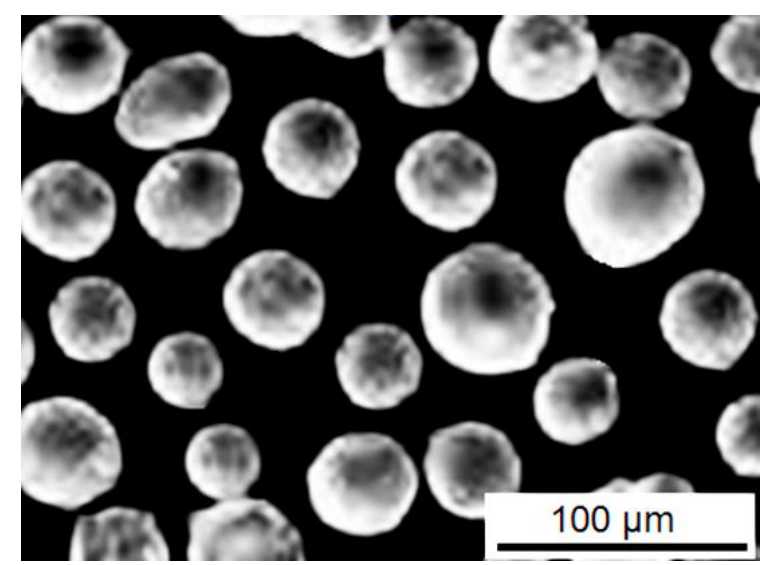

Figure 1. (SEM) Scanning electron micrograph of the NiCoCrA/Y powder particles

Slika 1. (SEM) skening elektronska mikrofotografija čestica praha NiCoCrAlY

The substrates on to which the coatings were deposited, for testing micro-hardness, tensile bond strength and for assessing the microstructure in deposited state, were made of Č.4171 (X15Cr13 EN10027) steel in thermally untreated condition. Dimensions of the specimens, for testing microhardness and microstructure evaluation, were $70 \times 20 \times 1.5 \mathrm{~mm}$ according to standard [18].

For testing of tensile bond strength of the coating with the substrate in deposited state, the dimensions of the samples were $\varnothing 25 \times 50 \mathrm{~mm}$ according to standard [18]. Samples for microstructure examination of the coating after heat treatment were made of an IN738LC alloy $20 \times 10 \times 5$ $\mathrm{mm}$ in size.

Evaluation of mechanical properties of the layers was done by examining micro-hardness using the $\mathrm{HV}_{0.3}$ method and testing of the bond strength bytension method.

Microhardness measurement was carried out in the direction along the lamellae in the middle and at the ends of the samples. Five value readings were done. This paper presents the mean value of microhardness of the coating. The test method for tensile bond strength was the tension method. Testing took place at room temperature with a tensile speed of $1 \mathrm{~mm} / 1 \mathrm{~min}$. This paper presents the mean value of tensile bond strength. The microstructure of the layers of NiCoCrAlY coating in deposited state was examined at the ends and in the middle of the sample by optical microscopy (OM).

Analysis of the share of micropores was performed by examining 5 photos at 200X magnification. The morphology of the powder particles, the morphology of the coating surface in deposited state and the microstructure of the coating after heat-treatment in etched state was examined on a Scanning Electron Microscope (SEM). Etching of the coating was carried out in the reagent $\mathrm{CuSO} 4+\mathrm{HCl}$ aqueous solution.

The NiCoCrAIY powder deposition was done at low pressure with the VPS system of the Plasma Technik AG Company which has an A-2000 control panel and an F4 plasma gun. The deposition was done with a mixture of $\mathrm{Ar}-\mathrm{H}_{2}$ plasma gases. Before the powder deposition process, the surfaces of the substrate were roughened with particles of white corundum 0.7-1.5 $\mathrm{mm}$ in size. After the roughening the surfaces of the substrate were cleaned and then preheated using a transferred arc at a temperature of 750 to $800^{\circ} \mathrm{C}$. In Table 1 shown are VPS parameters of NiCoCrAlY alloy powder deposition.

Table 1. The vacuum plasma spray parameters

Tabela 1. Vakuum plazma sprej parametri

\begin{tabular}{|l|c|}
\hline \multicolumn{1}{|c|}{ Parameters } & Values \\
\cline { 2 - 2 } & Spraying \\
\hline Plasma current, I $(\mathrm{A})$ & 750 \\
\hline Plasma voltage, $\mathrm{V}(\mathrm{U})$ & 58 \\
\hline $\begin{array}{l}\text { Primary plasma gas flow rate, } \\
\text { Ar (I/min) }\end{array}$ & 50 \\
\hline $\begin{array}{l}\text { Secondary plasma gas flow } \\
\text { rate, He, (I/min) }\end{array}$ & 3 \\
\hline $\begin{array}{l}\text { Carrier gas flow rate, Ar, } \\
\text { (I/min) }\end{array}$ & 35 \\
\hline Powder feed rate, $(\mathrm{g} / \mathrm{min})$ & 270 \\
\hline Stand-off distance, $(\mathrm{mm})$ & 140 \\
\hline Chamber pressure, $(\mathrm{mbar})$ & 8 \\
\hline Nozle diameter, $(\mathrm{mm})$ & 240 \\
\hline Speed of the gun, $(\mathrm{mm} / \mathrm{s})$ & \\
\hline
\end{tabular}

The thickness of the deposited layers of coating was $200-220 \mu \mathrm{m}$. Coating layers, which were heat-treated at $1150^{\circ} \mathrm{C}$ in a protective atmosphere of argon for 2 hours, were deposited on the IN738LCalloy substrate.

\section{RESULTS AND DISCUSSION}

\subsection{Results of coatings testing}

The NiCoCrAlY coating layers deposited at low pressure had a mean value of microhardness of $210 \mathrm{HV}_{0.3}$. The microhardness values were at the upper limit set by the powder manufacturer (183 $218 \mathrm{HV}$ ) [17]. The measured values show that on the substrate deposited were thick layers of coating 
with a low level of micro pores and oxide-free, as confirmed by analysis of the photomicrographs on an optical microscope (OM).

The surrounding atmosphere of the inert Ar gas at low pressure eliminated oxidation of melted powder particles. Pre-heating the substrate from 750 to $800^{\circ} \mathrm{C}$ made it possible to deposit thicker coating layers with high values of tensile bond strength. The mean value of tensile bond strength of the coatingat $67 \mathrm{MPa}$ is above the minimal value set by the manufacturer of the powder $>62 \mathrm{MPa}$ [17].

As the presence of micropores, unmelted particles and oxides is directly related to the values of tensile bond strength of the coating, the measured values indicate that their presence in the layers is reduced to an insignificant proportion or their presence is completely eliminated at low pressure, which was confirmed by analysis ofcoating microstructure on the optical microscope (OM).

In Figures 2, 3 and 4 shown are $\mathrm{OM}$ photomicrographs of the structure of the layers of the NiCoCrAlY coating at the ends and in the middle of the sample, which have been deposited on stainless steel substrates.

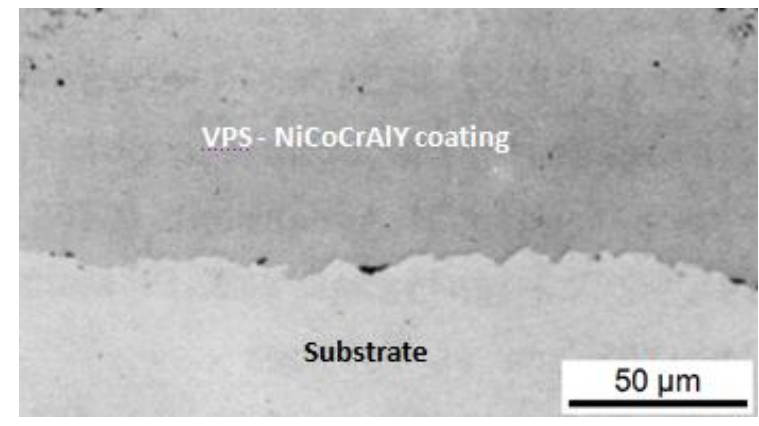

Figure 2. (OM) micrograph of VPS - NiCoCrA/Y coating, left edge of the sample

Slika 2. (OM) mikrofotografija VPS - NiCoCrA/Y prevlaka,leva strana uzorka

A qualitative analysis of the microstructure showed that at the interface between the substrate and the coating there are no present defects such as: discontinuity of the deposited layers, micro and macrocracks, micro and macropores and separating of the coating layers from the surface of the substrate. The coating is thick with a negligible proportion of micropores and without the presence of oxide lamellae. Analysis of the images showed that in the deposited coating present are micropores with an average content of $0.25 \%$. Preheating of the substrate allowed the molten particles to completely meld with previously deposited particles, because at the cross section of the coating there are no inter - lamellar boundaries observed. In the structure of the coating there are no unmelted powder particles present.

Figure 5 shows the SEM photomicrograph of the surface of the VPS - NiCoCrAlY coating. SEM analysis of the surface morphology of the coating shows complete melting of the powder particles and their proper deformation on the previously deposited layer. On the SEM photomicrograph marked with a red line are melted and spread powder particles. The fully melted powder particles formed thin discs - splats with fine precipitates at the edges and surfaces of the formed discs.

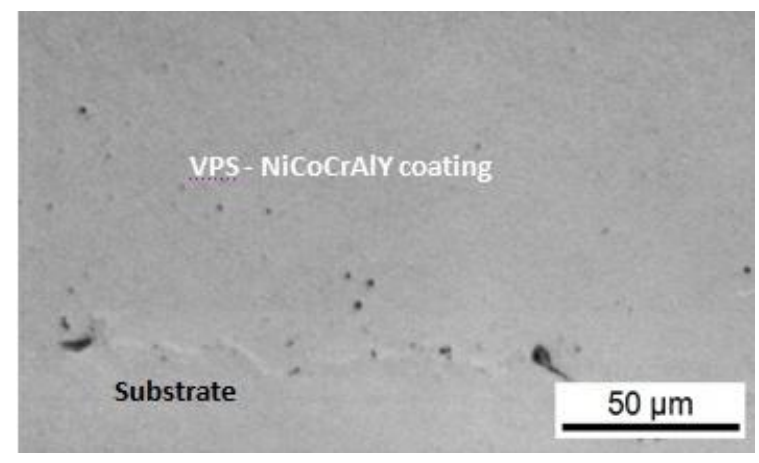

Figure 3. (OM) micrograph of VPS - NiCoCrA/Y coating, mid-simple

Slika 3. (OM) mikrofotografija VPS -NiCoCrA/Y prevlaka,sredina uzorka

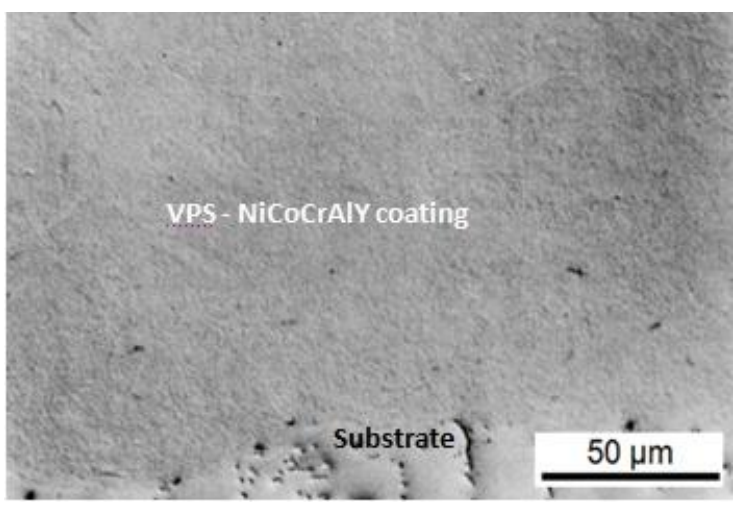

Figure 4. (OM) micrograph of VPS - NiCoCrA/Y coating, right edge of the sample

Slika 4. (OM) mikrofotografija VPS - NiCoCrAlY prevlaka, Idesna strana uzorka

Fine precipitates of irregular shape which are circled in green were formed as a result of collision of molten powder particles withthe previously deposited layer, wherein the parts of the molten particles at the ends break off and solidify as sediment in the coating. The molten powder particles in collision with the substrate formed a regular shape and as such created agood cohesive bond with the previously deposited layer. The SEM photomicrograph clearly shows a single black micropore up to $5 \mu \mathrm{m}$ in size circled in yellow. 


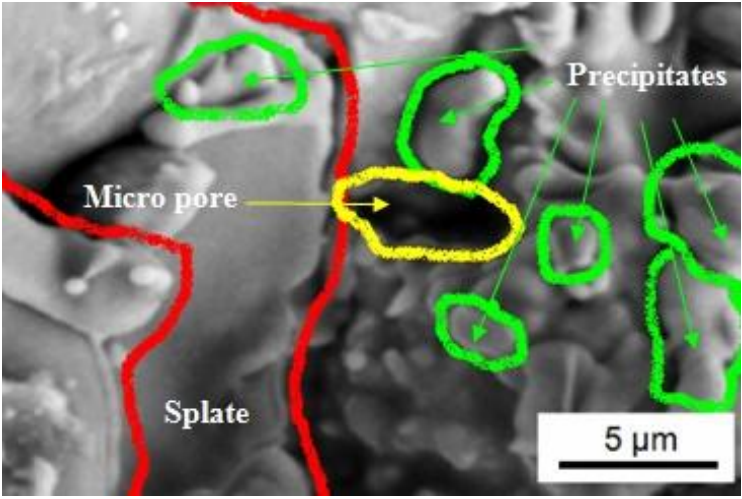

Figure 5. (SEM) Surface morphology of the VPS NiCoCrA/Y coating.

Slika 5. (SEM) morfologija površine VPS NiCoCrAlY prevlake

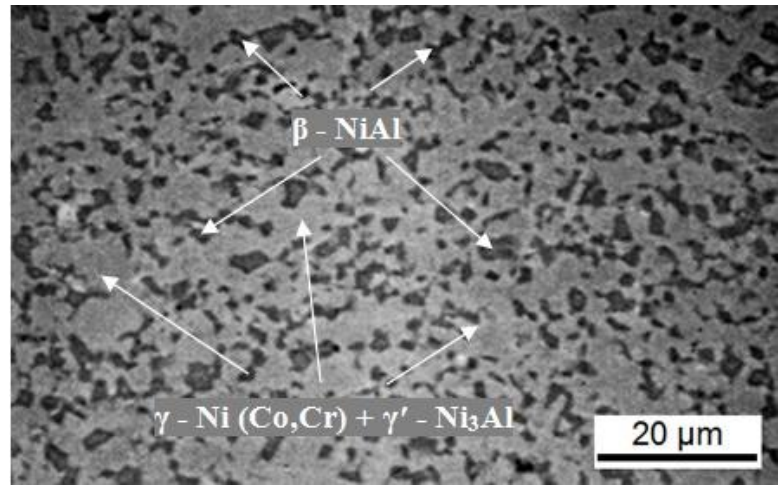

Figure 6. (SEM) micrograph of the etched microstructure of theNiCoCrA/Y coating after heat treatment at $1150{ }^{\circ} \mathrm{C} / 2$ hours.

Slika 6. (SEM) mikrografija nagrizena mikrostruktura prevlake NiCoCrA/Y posle termičkog tretmana na $1150^{\circ} \mathrm{C} / 2$ sata

The microstructure of the coating is homogenous on the whole cross section, consisting of two phases, one of which is light gray and other dark gray. Homogeneity is a consequence of increasing solubility of $\mathrm{Al}$ in the $\mathrm{y}$ phase at a temperature of $1150^{\circ} \mathrm{C}$. In the NiCoCrAlY coating formed was a series of phases with a high melting point, such as the $\gamma-\mathrm{Ni}(\mathrm{Co}, \mathrm{Cr}), \gamma^{\prime}-\mathrm{Ni}_{3} \mathrm{Al}$ and $\beta-\mathrm{NiAl}$ phase, which provides enhanced oxidation resistance.

The main phase of the coating of light gray color is a solid solution of chromium and cobaltin nickel $\mathrm{Y}-\mathrm{Ni}(\mathrm{Co}, \mathrm{Cr})$, which provides toughness of the coating. In the base of the coating of $\mathrm{Y}$ solid solution present arefine precipitates of they'- $\mathrm{Ni}_{3} \mathrm{Al}$ phase, which strengthen the coating and increase its resistance to high temperature creep together with the substrate $[15,16]$. The second phase of a dark gray color are precipitates of the $\beta$-NiAl phase which is a reservoir of $\mathrm{Al}$ and provides resistance of the coating to oxidation [19].

\section{CONCLUSIONS}

For this paper, the NiCoCrAlY coating was deposited using the vacuum plasma spray process. Analyzed were the coating mechanical properties and microstructure in deposited state and after heat treatment at $1150^{\circ} \mathrm{C}$ in a protective atmosphere of argon for 2 hours, based on which the following conclusions were made.

The mean value of microhardness of the VPS NiCoCrAlY coating was $210 \mathrm{HV}_{0.3}$. The microhardness values were at the upper limit set by the manufacturer of the powder, $218 \mathrm{HV}$. The measured values indicate that thick layers of coating were deposited on the substrates with a mean content of micropores of $0.25 \%$. Pre-heating of the substrate allowed depositing of thick coating layers with high values of tensile bond strength. The mean value of tensile bond strength of the deposited coating of 67MP ais above the minimum levelset by the powder manufacturer $>62 \mathrm{MPa}$.

The microstructure of the VPS - NiCoCrAIY coating after heat treatment in etched state is homogeneous. In the microstructure of the coating presentare precipitates of the $\beta-\mathrm{NiAl}$ phase dark gray in color that are uniformly distributed in thecoatingbase of the $\mathrm{y}-\mathrm{Ni}(\mathrm{Co}, \mathrm{Cr})+\mathrm{y}^{\prime}-\mathrm{Ni}_{3} \mathrm{Al}$ solid solutionof light gray color. The precipitates of the $\beta$ $\mathrm{NiAl}$ phase are a reservoir of Al which provides the coating resistance to oxidation.

In the coating base of the $\mathrm{Y}$ solid solution present are fine precipitates of the $\mathrm{Y}^{\prime}-\mathrm{Ni}_{3} \mathrm{Al}$ phase, which strengthen the coating and increase its resistance to high temperature creep, together with the substrate.

The VPS-NiCoCrAlY coating showed good mechanical properties and a homogeneous microstructure, which enables its successful application in hot sections of gas turbines for protection against high temperature oxidation.

\section{Acknowledgement}

This investigation was supported by Serbian Ministry of Education, Science and Technological Development (national projects Ol174004 \& TR34016).

\section{REFERENCE}

[1] M.Mrdak (2016) Properties of the $\mathrm{ZrO}_{2} \mathrm{MgO} / \mathrm{MgZrO}_{3} \mathrm{NiCr} / \mathrm{NiCr}$ triple-layer thermal barrier coating deposited by the atmospheric plasma spray process, Vojnotehnički glasnik / Military Technical Coyrier, 64, 2, 411-430.

[2] M.Mrdak (2017) Mechanical properties and the microstructure of the plasma-sprayed $\mathrm{ZrO}_{2} \mathrm{Y}_{2} \mathrm{O}_{3}$ $\mathrm{ZrO}_{2} \mathrm{Y}_{2} \mathrm{O}_{3} \mathrm{CoNiCrAIY} /$ CoNiCrAlY coating, Vojnotehnički glasnik / Military Technical Courier, $65,1,30-44$.

[3] M.R.Mrdak (2017) Structure and properties of Ni22Cr10Al1Y coatings deposited by the vacuum plasma spray process, Vojnotehnički glasnik / Military Technical Courier, 65(2), 378-391. 
[4] M.Mrdak (2017) Karakterizacija plazma sprej bioinertne kompozitne prevlake $\mathrm{Al}_{2} \mathrm{O}_{3} 25$ tež.\%( $\left.\mathrm{ZrO}_{2} 8 \% \mathrm{Y}_{2} \mathrm{O}_{3}\right)$, Zastita materijala, 58(4), 509-515.

[5] Y.Itoh, M.Saitoh (2005) Mechanical Properties of Overaluminized MCrAlY Coatings at Room Temperature, Journal of Engineering for Gas Turbines and Power, 127, 807-813.

[6] J.R.Nicholls (2000) Designing oxidation resistant coatings, Journal of metals, 52(1), 28-35.

[7] R.Prescott, M.J.Graham (1992) The formation of alumina oxide scales on high-temperature alloys, Oxidation of Metals, 38(3-4), 233-254.

[8] M.Kutz (2005) Handbook of environmental degradation of materials, William Andrew Inc., New York.

[9] T.J.Nijdam, W.G.Sloof (2006) Combined preannealing and pre-oxidation treatment for the processing of thermal barrier coatings on NiCoCrAIY bond coatings. Surface \& Coatings Technology, 201(7), 3894-3900.

[10] T.J.Nijdam, W.G.Sloof (2007) Effect of reactive element oxide inclusions on the growth kinetics of protective oxide scales. ACTA Materialia, 55(17), 5980-5987.

[11] B.Pint, K.More (2009) Characterization of alumina interfaces in TBC systems. Journal of Materials Science, 44(7), 1676-1686.

[12] P.Poza, P.S.Grant (2006) Microstructure evolution of vacuum plasma sprayed CoNiCrAlY coatings after heat treatment and isothermal oxidation, Surface and Coatings Technology, 201(6), 28872896.
[13] J.Angenete, K.Stiller, E.Bakchinova (2004) Microstructural and microchemical development of a simple and Pt-modified aluminide coatings during long term oxidation at $1050{ }^{\circ} \mathrm{C}$, Surface and Coatings Technology, 176, 272-283

[14] M.W.Chen, M.L.Glynn, R.T.Ott, T.C.Hufnagel, K.J.Hemker (2003) Chracterisation and modeling of a martensitic transformation in a platinum modified diffusion aluminide bond coat for thermal barrier coatings, ACTA Materialia, 51, 4279-4294.

[15] K.Fritscher, Y.Lee (2005) Investigation of an assprayed NiCoCrAlY overlay coating - microstructure and evolution of the coating, Materials and Corrosion, 56(1), 5-14.

[16] J.Toscano, A.Gil, T.Huttel, E.Wessel, D.Naumenko, L.Singheiser, W.J.Quadakkers (2007) Temperature dependence of phase relationships in different types of MCrAlY-coatings, Surface and Coatings Technology, 202(4-7), 603-607.

[17] Material Product Data Sheet (2012) Nickel Cobalt Chromium Aluminum Yttrium (NiCoCrAIY) Thermal Spray Powders, Amdry 365-1, DSMTS-0093.2, Sulzer Metco.

[18] ASTM C633-1 (2008) Standard Test Method for Adhesion or Cohesion Strength of Thermal Spray Coatings, Reapproved.

[19] M.Funk, K.Ma, C.Eberl, J.M.Schoenung, M.Göken, K.J.Hemer (2011) High-Temperature Mechanical Behavior of End-of-Life Cryomilled NiCrAlY Bond Coat Materials, Metallurgical and materials transactions A, 42A, 2233-2241.

\section{IZVOD}

\section{KARAKTERIZACIJA VAKUUM PLAZMA SPREJ PREVLAKE NiCoCrAIY OTPORNE NA VISOKOTEMPERATURNU OKSIDACIJU}

Zaštitna vakuum plazma sprej VPS - NiCoCrAlY prevlaka se koriste na sekcijama gasnih turbina da bi se omogućio duži $i$ pouzdaniji rad sekcijama izloženim agresivnom napadu visokotemperaturne oksidacije. Deponovanje praha od legure NiCoCrAlY urađeno je vakuum plazma sprej sistemom firme Plasma Technik - AG na upravljačkoj jedinici A-2000 sa plazma pištoljem F4. Za ispitivanje mehaničkih karakteristika i mikrostrukture NiCoCrAlY prevlake, prah je deponovan na substratima od čelika Č.4171 (X15Cr13 EN10027). Za ispitivanje mikrostrukture prevlake u termički obrađenom stanju, prah je deponovan na substratu od legure IN738LC, koji je pre depozicije praha bio predgrejan na temperaturi od 750 do $800^{\circ} \mathrm{C}$. Prevlaka je sa substratom od legure IN738LC termički tretirana na $1150^{\circ} \mathrm{C}$ u trajanju od 2 sata u zaštitnoj atmosferi argona. Mehanička ispitivanja mikrotvrdoće prevlake urađena su metodom $\mathrm{HV}_{0.3}$ i zatezna čvrstoća spoja metodom na zatezanje. Morfologija čestica praha i morfologija površine deponovane prevlake ispitana je na skening elektronskom mikroskopu (SEM). Mikrostruktura slojeva prevlake u deponovanom stanju ispitana je na optičkom mikroskopu (OM). Posle termičke obrade sprovedeno je nagrizanje prevlake u reagensu $\mathrm{CuSO}_{4}+\mathrm{HCl}$ vodeni rastvor. Analiza mikrostrukture prevlake posle nagrizanja urađena je na SEM-u, na osnovu čega se dala ocena kvaliteta difuzione VPS - NiCoCrAlY prevlake.

Ključne reči: vakuum plazma sprej proces, NiCoCrAY, mikro struktura, mikro tvrdoća, zatezna čvrstoća spoja.

\section{Naučni rad}

Rad primljen: 20. 05. 2019.

Rad prihvaćen: 30. 07. 2019.

Rad je dostupan na sajtu: www.idk.org.rs/journal

(c) 2019 Authors. Published by Inženjersko društvo za koroziju. This article is an open access article distributed under the terms and conditions of the Creative Commons Attribution 4.0 International license (https://creativecommons.org/licenses/by/4.0/) 